\title{
EFFECT OF SPRAYING SILICON AND SOME NUTRIENTS ON GROWTH, PALM NUTRITIONAL STATUS, YIELD AND FRUIT QUALITY OF ZAGHLOUL DATE PALMS. 1- EFFECT OF SPRAYING SILICON AND SOME NUTRIENTS ON GROWTH AND PALM NUTRITIONAL STATUS OF ZAGHLOUL DATE PALMS
}

\author{
Ahmed, M.M.A. Akl; Faissal F. Ahmed"; Hamdy I.M. Ibrahim*; Abbas \\ S.A. Saad ${ }^{* * *}$; and Magdy, N. R. Salama ${ }^{* * *}$ \\ "Hort. Department, Faculty of Agriculture, Minia Univ., Egypt. \\ ** Tropical Fruit Res. Dept., Hort. Res. Instit., ARC, Giza, Egypt
}

ABSTRACT

During 2015 and 2016 seasons, Zaghloul date palms at Dahmro village, Maghagha district, Minia Governorate treated with silicon and/or some nutrients namely $\mathrm{N}, \mathrm{P}, \mathrm{K}, \mathrm{Mg}, \mathrm{Zn}, \mathrm{Fe}, \mathrm{Mn}, \mathrm{Cu}$ and $\mathrm{B}$. The merit was examining the effect of these nutrients on growth and palm nutritional status.

Treating the palms three times with silicon and/or macro and micronutrients caused a remarkable stimulation on number of new leaves/palm, leaf length, pinnae area, number of pinnaelleaf, leaf area, number of spines per leaf and spine length and percentages of $N, P, K$ and $\mathrm{Mg}$ in the leaves over the control treatment. Using macro and micronutrients was superior than the single application of silicon on enhancing all growth aspects and leaf chemical components. Combined application of silicon and nutrients surpassed the application of each alone in this respect.

Conclusively, for enhancing growth and palm nutritional status of Zaghloul date palms, it is suggested to spray the palms with a mixture of silicon, $N, P, K, M g, Z n, F e, M n, C u$ and $B$ three times.

Keywords: Zaghloul, date palms, Si, N, P, K, Mg, Zn, Fe, Mn, Cu, B, growth palm, nutritional status.

\section{INTRODUCTION}

Silicon has many functions in plant nutrition. It has many regulatory roles in enhancing the tolerance of plants to biotic and abiotic stresses, water retention, photosynthesis, plant pigments and building of carbohydrates and 
natural growth regulators (Gang et al., 2003; Lux et al., 2003; Ma, 2004 and Hattori et al., 2005). Macro and micronutrients are responsible for promoting cell division and the biosynthesis of plant pigments, organic foods, antioxidants, vitamins, amino acids and natural hormones (Marschner, 1995).

Previous studies showed that silicon (Gad El-Kareem et al., 2014; Omar, 2015 and Youssef, 2017) and different nutrients (Deskouky et al., 2007; Shahin, 2007; Abdalla, 2008 and Mohamed and Mohamed, 2013) were favourable in enhancing vegetative growth characteristics and leaf mineral content in various date palm cvs.

The target of this study was elucidating the effect of silicon as well as some macro and micro nutrients on growth and palm nutritional status of Zaghloul date palms.

\section{MATERIALS AND METHODS}

This study was conducted during 2015 and 2016 seasons in a private date palm orchard situated at Dahmro village, Maghagha district, Minia Governorate on 24 (19-years old) of Zaghloul date palms. These palms produced through conventional propagation by offshoots as well as characterized by regular bearing. The selected palms are uniform in vigour, healthy, good physical conditions, free from insects, diseases and damages. They are planted at $10 \times 10$ meters apart (42 palms/ feddan). The selected palms were irrigated with Nile water through surface irrigation system. The texture of soil is clay.

The objective of this study was examining the effect of foliar application of silicon as well as some macro and micro nutrients on some vegetative growth characteristics and leaf chemical composition of Zaghloul date palms grown under middle Egypt conditions.

Hand pollination of all the selected palms was achieved by inserting ten fresh male strands into the center of one female spathae (Hussein et al., 1987) using the same source of pollens to avoid residues of metaxenia. Pollination was carried out throughout two days after female spathes cracking at the day time of afternoon to prevent contamination of the investigated pollens. Every bunch was bagged after pollination by white paper bags which were tied at the ends using a piece of cotton for aeration and the bags were shaken lightly to ensure pollens distribution and they were removed after one month (Musa, 1981). Number of bunches per palm was adjusted to ten bunches and leaf bunch ratio was maintained at $8: 1$. 
The texture of soil is clay. Physical and chemical properties of the experimental soil at $0.0-90 \mathrm{~cm}$ depth are presented in Table (1) according to the procedures of Black et al, (1965) and Carter (1993).

All the selected Zaghloul date palms received program of fertilization consists of $10 \mathrm{~kg}$ plant compost $(2.5 \% \mathrm{~N}), 5.0 \mathrm{~kg}$ ammonium sulphate, (20.6 $\% \mathrm{~N}) 1.5 \mathrm{~kg}$ triple calcium superphosphate $\left(37.5 \% \mathrm{P}_{2} \mathrm{O}_{2}\right)$ and $1.5 \mathrm{~kg}$ potassium sulphate $\left(48 \% \mathrm{~K}_{2} \mathrm{O}\right)$ per each palm. Plant compost was added once at the middle of Jan. Ammonium sulphate was splitted into three equal batches and added at the first week of Mar., May and July.

Phosphate fertilizer was splitted into two equal batches. The first was added at the middle of January and the second one was applied just after fruit setting (last week of April). Potassium sulphate was applied twice before pollination (last week of Feb.) and just after fruity setting (last week of April). Another horticultural practices were carried out as usual.

The study included the following eight treatments from different nutrients namely $\mathrm{N}, \mathrm{P}, \mathrm{K}, \mathrm{Mg}, \mathrm{Zn}, \mathrm{Fe}, \mathrm{Mn}, \mathrm{Cu}, \mathrm{B}$ and Si:-

1-Control (palm sprayed with water)

2-Spraying Potassium silicate at $0.1 \%$

3-Spraying $\mathrm{Zn}, \mathrm{Fe}, \mathrm{Mn}, \mathrm{Cu}$ and $\mathrm{B}$.

4-Spraying $\mathrm{N}+\mathrm{P}+\mathrm{K}+\mathrm{Mg}$

5-Spraying $\mathrm{Si}+\mathrm{Zn}+\mathrm{Fe}+\mathrm{Mn}+\mathrm{Cu}+\mathrm{B}$

6-Spraying $\mathrm{Si}+\mathrm{N}+\mathrm{P}+\mathrm{K}+\mathrm{Mg}$

7-Spraying $\mathrm{Zn}+\mathrm{Fe}+\mathrm{Mn}+\mathrm{Cu}+\mathrm{B}+\mathrm{N}+\mathrm{P}+\mathrm{K}+\mathrm{Mg}$

8-Spraying all nutrients (N, P, K, Mg, Zn, Fe, Cu, B, Si) together.

Each treatment was replicated three times, one date palm per each. Macronutrients namely $\mathrm{N}, \mathrm{P}, \mathrm{K}$ and $\mathrm{Mg}$ were foliage sprayed in the sources of urea $(46.5 \% \mathrm{~N})$, orthophosphoric acid $\left(85 \% \mathrm{P}_{2} \mathrm{O}_{2}\right)$, potassium sulphate $\left(48 \% \mathrm{~K}_{2} \mathrm{O}\right)$ and magnesium sulphate $(9.6 \% \mathrm{~N})$ each at $0.5 \%(5 \mathrm{~g} / \mathrm{L})$, respectively. Micronutrients namely $\mathrm{Zn}, \mathrm{Fe}$ and $\mathrm{Mn}$ were applied in the chelated form (13\% of each element) at $0.05 \%$ ( $0.5 \mathrm{~g} /$ water). Cupper was added in the cupper sulphate form at $0.025 \%(0.25 \mathrm{~g} / \mathrm{L})$. Boron was added in the form of boric acid $(17 \% \mathrm{~B})$ at $0.025 \%(0.25 \mathrm{~g} / \mathrm{l})$. Potassium silicate liquid $\left(25 \%+10 \% \mathrm{~K}_{2} \mathrm{O}\right)$ was easily soluble in water and it was dissolved in triton $\mathrm{B}$ as a wetting agent at $0.1 \%$ before application. The selected palms received three sprays of each nutrient started two weeks before hand pollination (before spathe cracking, last week of Feb.), just after fruit setting ( $1^{\text {st }}$ week of Apr.) and at one month later (ist week of May). 
Table (1): Analysis of the tested soil

\begin{tabular}{|l|c|}
\hline Constituents & Values \\
\hline Particle size distribution & 8.5 \\
\hline Sand \% & 21.0 \\
\hline Silt \% & 70.5 \\
\hline clay \% & Clay \\
\hline Texture & 8.0 \\
\hline $\mathrm{pH}(1: 2.5$ extract) & 0.75 \\
\hline $\mathrm{EC}(1: 2.5$ extract $)$ mmhos/ $1 \mathrm{~cm} 25^{\circ} \mathrm{cm}$ & 1.9 \\
\hline Organic matter \% & 1.9 \\
\hline Total CaCO3 \% & 0.09 \\
\hline Total N \% & 3.3 \\
\hline $\mathrm{P}$ ppm (Oslen) & 410.0 \\
\hline $\mathrm{K} \mathrm{ppm} \mathrm{(} \mathrm{ammonium} \mathrm{acetate)}$ & \\
\hline Available micronutrients $($ EDTA, ppm): & 1.8 \\
\hline $\mathrm{Fe}$ & 2.1 \\
\hline $\mathrm{Zn}$ & 1.9 \\
\hline $\mathrm{Mn}$ & 0.7 \\
\hline $\mathrm{Cu}$ & \\
\hline
\end{tabular}

Triton B as a wetting agent was added to all nutrient solutions. Randomized complete block design (RCBD) was followed in which this experiment included eight treatments and each treatment replicated three times, one palm per each.

During the two seasons, the following measurements were recorded:

\section{1- Measurements of vegetative growth characteristics:}

At the first week of July, number of pinnae/ new leaf, as well as, area of pinnae and leaf $(\mathrm{cm})$ were recorded in the five labeled leaves / palm. For measuring pinnae area $\left(\mathrm{cm}^{2}\right)$ one six month old labeled leaf per palm was removed and the four medium pinnae were taken and using the following equation that outlined by Ahmed and Morsy (1999). Pinnae area $\left(\mathrm{m}^{2}\right)=$ 0.37 (length $\mathrm{x}$ width) +10.29 then the area for the whole leaf $\left(\mathrm{m}^{2}\right)$ was obtained from multiplying the pinnae area by number of pinnae per leaf. In 
addition, number of new leaves per palm was also recorded. Number of spines/ leaf and spine length $(\mathrm{cm})$ were measured.

\section{2- Measurements of leaf content of $N, P, K$ and $M g$ :}

In both seasons and in early September, twenty pinnae from the middle of leaf (according to Summer, 1985) for each palm were selected. As soon as the leaflet samples were picked, they were cleaned with cloth damp to remove any residues that might affect the results. The leaflets were oven dried at $70^{\circ} \mathrm{C}$ for 48 hours, ground and stored in small pockets prior analysis. Accurate plant material (0.2 g) was digested using hydrogen peroxide and sulfuric acid as recommended by (Peach and Tracey, 1968). The digested materials were transferred quantitatively to $50 \mathrm{ml}$ volumetric flask and raised up to the uniformity volume. Then, the following nutrients were determined:

1- Nitrogen $\%$ was determined by the modified micro kjeldahl method as described by Chapman and Pratt, 1965) and Page et al., (1982).

2- Phosphorus \% was determined by using spekol spectrophoyometer (Evenhus and Deward, 1980 and Cottenie et al., 1982).

3- Potassium \% was determined by using Flame photometer according to the procedure reported by Jones et al., (1991).

4- Magnesium \% as well as leaf content of $\mathrm{Fe}, \mathrm{Zn}, \mathrm{Mn}$ and $\mathrm{Cu}$ (as ppm) were determined using atomic absorption spectrophotometer Perkin Elmer model 5000 according to Pregel (1945) and Piper (1950).

Thereafter, the obtained data during the two seasons were collected, tabulated and subjected to the proper statistical analysis of variance method reported by Gomez and Gomez (1984) and Mead et al., (1993). The differences between treatment means were differentiated using New L.S.D at $5 \%$ parameter.

\section{RESULTS}

\section{1- Some vegetative growth characteristics:}

\section{1-1. Number of new leaves per palm:}

Data in Table (2) show that the number of leaves per palm in the first season of study was not significantly affected by single and combined applications of silicon, as well as some macro and micronutrient applications. 
AHMED AKL et al.

\begin{tabular}{|c|c|c|c|c|c|c|c|c|c|c|c|}
\hline 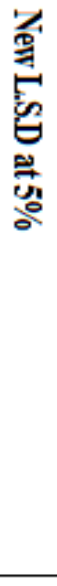 & 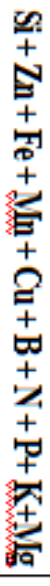 & 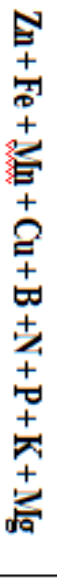 & 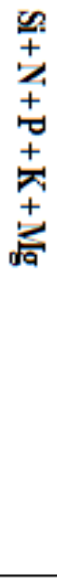 & 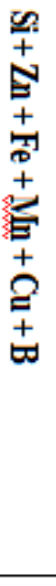 & 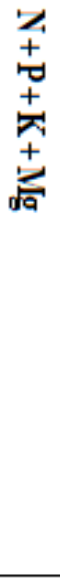 & $\begin{array}{l}\mathbf{E} \\
+ \\
+ \\
+ \\
+ \\
+ \\
\vdots \\
+ \\
+ \\
\Xi \\
+ \\
+\end{array}$ & 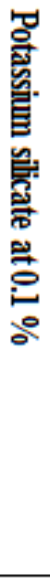 & 兽 & & $\begin{array}{l}\text { 营 } \\
\text { 葛 } \\
\text { 惫 }\end{array}$ & 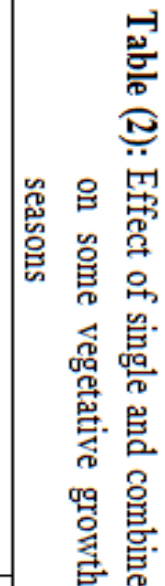 \\
\hline 光 & 今̊ & 잉 & క̊ & No & $\ddot{\circ}$ & 응 & : & : & 苍 & \multirow{2}{*}{ 总兑 } & \\
\hline$\stackrel{a}{a}$ & $\tilde{a}$ & $\begin{array}{l}\text { W } \\
0\end{array}$ & $\stackrel{+}{+}$ & $\begin{array}{c}\omega \\
0\end{array}$ & $\underset{0}{N}$ & $\stackrel{\stackrel{0}{0}}{\circ}$ & : & $\stackrel{\bullet}{\infty}$ & 荢 & & \\
\hline 官 & $\stackrel{\omega}{\vdots}$ & No & $\begin{array}{l}N \\
\infty \\
\infty\end{array}$ & $\stackrel{N}{\rightleftharpoons}$ & $\stackrel{N}{\sim}$ & $\underset{\omega}{\omega}$ & $\stackrel{\omega}{\omega}$ & $\stackrel{n}{\circ}$ & 苍 & \multirow{2}{*}{ 定惫 } & \\
\hline$\stackrel{\ominus}{6}$ & $\stackrel{\omega}{\bullet}$ & io & مo & $\stackrel{N}{\sim}$ & $\stackrel{N}{u}$ & $\stackrel{\sim}{\omega}$ & $\stackrel{\sim}{*}$ & $\underset{+}{\vec{b}}$ & 荅 & & \\
\hline$\stackrel{n}{\circ}$ & $\underset{\omega}{\omega}$ & $\underset{ \pm}{\stackrel{\infty}{\sim}}$ & $\begin{array}{l}\vec{b} \\
\text { త్ర }\end{array}$ & $\begin{array}{l}\text { bొ } \\
\infty \\
\infty\end{array}$ & $\underset{\omega}{\stackrel{\omega}{\omega}}$ & 茨 & $\begin{array}{l}t \\
\infty \\
0 \\
w\end{array}$ & $\begin{array}{l}\stackrel{t}{\omega} \\
\omega\end{array}$ & 苍 & \multirow{2}{*}{ 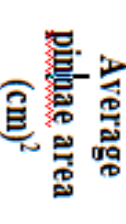 } & \\
\hline 㟧 & ని & $\underset{\sim}{\infty}$ & $\begin{array}{l}\vec{b} \\
\text { vo }\end{array}$ & 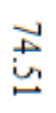 & $\begin{array}{l}2 \\
\infty \\
+ \\
b\end{array}$ & 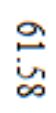 & $\begin{array}{l}\text { 品 } \\
\text { 吉 }\end{array}$ & $\begin{array}{l}\vec{v} \\
\stackrel{v}{u}\end{array}$ & 苍 & & \\
\hline 菭 & $\begin{array}{l}\stackrel{N}{0} \\
0 \\
0\end{array}$ & $\stackrel{\Xi}{\stackrel{\Xi}{0}}$ & $\begin{array}{l}\overrightarrow{8} \\
0\end{array}$ & $\underset{0}{\stackrel{\bullet}{0}}$ & \begin{tabular}{l}
$\stackrel{\infty}{0}$ \\
\hdashline
\end{tabular} & 离 & 光 & $\underset{0}{\Xi}$ & 苍 & \multirow{2}{*}{ 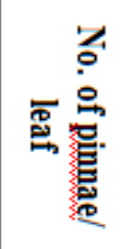 } & \\
\hline in & $\begin{array}{l}N \\
N \\
0\end{array}$ & $\underset{0}{*}$ & 呆 & : & $\underset{0}{\overrightarrow{0}}$ & $\stackrel{0}{\circ}$ & 0 & : & 总 & & \\
\hline
\end{tabular}


However, in the second season, it was significantly varied among the most investigated eight treatments. Combined applications of silicon as well as macro or micro nutrients significantly was followed by stimulating such growth aspects. Using silicon with both macro and micronutrients was significantly favourable than using nutrients alone in enhancing the number of new leaves/ palm. Using macro and micr5o nutrients together significantly surpassed the application of each alone in this respect. The maximum values (26 leaf) was recorded on the palms that received three sprays of silicon and a mixture of both macro and micro nutrients in the second season. The lowest value (18 leaf/palm) was recorded on untreated palms.

\section{1-2. Leaf length:}

It is clear from the obtained data in Table (2) that subjecting Zaghloul date palms to single and combined applications of silicon as well as some macro $(\mathrm{N}, \mathrm{P}, \mathrm{K}, \mathrm{Mg})$ and micro $(\mathrm{Zn}, \mathrm{Fe}, \mathrm{Mn}, \mathrm{Cu}$ and $\mathrm{B})$ nutrients significantly enhanced the leaf length compared to the control treatment. The promotion on such growth characteristic was significantly related to mixing silicon with macro and micronutrients. Using silicon in combined with macro and/or micronutrients was significantly superior than using macro and/or micronutrients alone. Spraying macro and/or micronutrients was significantly favourable than using silicon alone in this respect. The maximum values (3.11 $\& 3.17 \mathrm{~m}$ ) were recorded on the palms that received three sprays of a mixture of silicon and all nutrients during both seasons, respectively. The untreated palms produced the lowest values $(2.00 \& 1.94 \mathrm{~m})$ during 2015 and 2016 seasons, respectively. Similar trend was noticed during both seasons.

\section{1-3. Average pinnae area:}

Data in Table (2) show that Pinnae area of Zaghloul date palms was significantly improved in response to treating the palms three times with single and combined applications of silicon and different macro and micronutrients compared to the control treatment. Using macro and/or micronutrients was significantly preferable than using silicon in enhancing such growth trait. Combined applications of silicon alone and both macro and micro nutrients was significantly superior than using each alone in improving pinnae area. Using silicon and all macro and micronutrients produced the maximum values (103.37 \& $\left.96.63 \mathrm{~cm}^{2}\right)$ during both seasons, respectively. The untreated palms produced the minimum values $\left(45.73 \& 49.75 \mathrm{~cm}^{2}\right)$ during 2015 and 2016 seasons, respectively. These results were true during both seasons. 


\section{1-4. Number of pinnae per leaf:}

It is clear from the obtained data Table (2) that subjecting Zaghloul date palms three times to silicon as well as macro and micronutrients either singly or in various combinations significantly was followed by enhancing the number of pinnae per leaf relative to the control treatment. Using silicon alone caused unsignificant promotion on such growth aspects relative to the control treatment. However, using macro and micronutrients either alone or in various combination with silicon significantly improved the number of pinnae per leaf over the control treatment. Using silicon besides macro or micronutrients significantly was accompanied with enhancing such growth trait compared with using nutrients alone. Treating the palms with all nutrients $(\mathrm{Si}+\mathrm{N}+\mathrm{P}+$ $\mathrm{K}+\mathrm{Mg}+\mathrm{Zn}+\mathrm{Fe}+\mathrm{Mn}+\mathrm{Cu}+\mathrm{B})$ together gave the maximum values $(218 \&$ 222 pinnae/leaf) and the untreated palms produced the lowest values $(171.0 \&$ 180.0 pinnae/leaf) during 2015 and 2016 seasons, respectively.

\section{1-5. Average leaf area:}

Data in Table (3) show that the leaf area was slightly enhanced in response to using silicon as well as macro and micro nutrients signal compared with control treatment in the first season of study. However, using silicon with macro and/or micronutrients had significant promotion on the leaf area in the seasons compared with control treatment. In 2016 season all treatments had significant stimulation on the leaf area above the control. The maximum leaf area $\left(2.250 \& 2.145 \mathrm{~m}^{2}\right)$ were recorded on the palms that received silicon and all nutrients together during 2015 and 2016 seasons, respectively. The untreated palms produced the lowest values $\left(0.782\right.$ and $\left.0.895 \mathrm{~m}^{2}\right)$ during 2015 and 2016 seasons, respectively.

\section{1-6. Number of spines/leaf:}

Data in Table (3) show that the number of spines/leaf was significantly promoted by treating the palms with macro and/or micronutrients as well as all combinations of silicon and these nutrients relative to the control treatment. Using silicon alone had no significant promotion on the number of spines/leaf. Using macro and/or micronutrients was significantly superior than using silicon in enhancing the number of spines /leaf. Using silicon besides macro and / or micronutrients was significantly followed by enhancing such growth trait than using macro and/or micronutrients alone. Treating the palms with silicon and all nutrients together gave the maximum values $(30$ \& 33 spine/leaf) while in the untreated palm, number of pinnae/leaf was $16.0 \& 18.0$ 


\begin{tabular}{|c|c|c|c|c|c|c|c|c|c|c|c|}
\hline 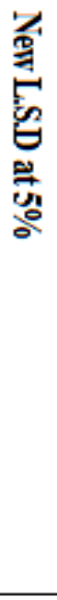 & 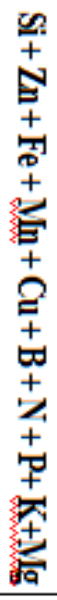 & 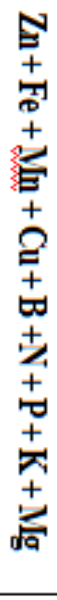 & 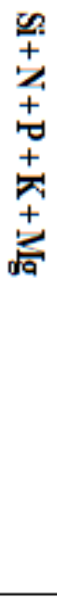 & 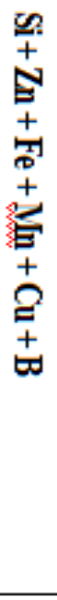 & 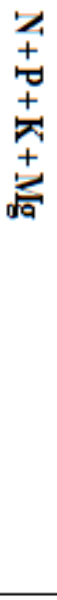 & 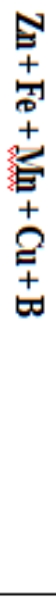 & 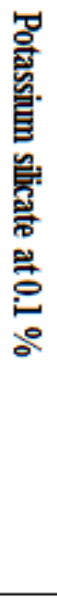 & 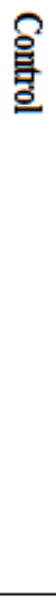 & & $\begin{array}{l}\text { 营 } \\
\text { 蒫 } \\
\text { 惫 } \\
\text { 点 }\end{array}$ & 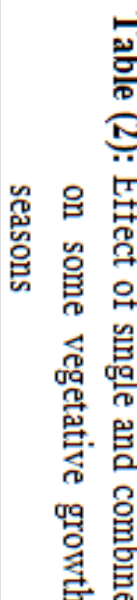 \\
\hline 兄 & O̊ & O̊ & $\stackrel{\circ}{\circ}$ & $\stackrel{1}{\circ}$ & O̊ & $\stackrel{\circ}{\circ}$ & $\overrightarrow{0}$ & $\overrightarrow{0}$ & 总 & \multirow{2}{*}{ 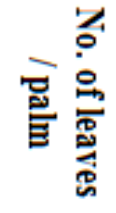 } & 官 \\
\hline$\vec{a}$ & $\tilde{\sigma}$ & No & $\stackrel{+}{+}$ & $\stackrel{\omega}{\omega}$ & $\begin{array}{l}N \\
0\end{array}$ & $\stackrel{\sim}{\stackrel{0}{0}}$ & : & $\begin{array}{l}\infty \\
0\end{array}$ & 苍 & & 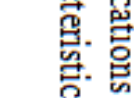 \\
\hline$\stackrel{0}{\infty}$ & $\stackrel{\omega}{\boxminus}$ & 沉 & N & $\stackrel{\sim}{\sim}$ & $\stackrel{N}{\sim}$ & $\underbrace{N}_{\omega}$ & $\stackrel{N}{\omega}$ & $\ddot{\circ}$ & 苍 & \multirow{2}{*}{ 鲁兽 } & 号 \\
\hline 官 & $\stackrel{\omega}{\Xi}$ & No & No & $\stackrel{\sim}{\sim}$ & N & $\stackrel{\omega}{\omega}$ & $\stackrel{N}{:}$ & $\underset{+}{\circ}$ & 苂 & & \\
\hline$\stackrel{n}{\circ}$ & $\begin{array}{l}\overrightarrow{\mathrm{D}} \\
\underset{\mathrm{w}}{\mathrm{w}}\end{array}$ & $\underset{\sim}{\sim}$ & $\begin{array}{l}\text { అै } \\
\text { فे }\end{array}$ & $\begin{array}{l}0 \\
\infty \\
\infty \\
\end{array}$ & $\begin{array}{l}\stackrel{a}{\omega} \\
\dot{\omega} \\
\bullet\end{array}$ & 瓷 & $\begin{array}{l}t \\
\infty \\
心 \\
u\end{array}$ & 点 & 苍 & \multirow{2}{*}{ 总 } & \\
\hline ü & $\begin{array}{l}\circ \\
\text { ᄋे } \\
\text { 'े }\end{array}$ & $\underset{\sim}{\infty}$ & $\begin{array}{l}\text { vै } \\
\text { bo }\end{array}$ & 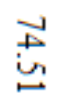 & $\begin{array}{l}2 \\
\infty \\
10\end{array}$ & $\stackrel{a}{\stackrel{\leftrightarrow}{\leftrightarrow}}$ & $\begin{array}{l}\text { 兄 } \\
\text { 古 }\end{array}$ & \begin{tabular}{l}
$\vec{b}$ \\
\multirow{u}{*}{}
\end{tabular} & 苍 & & 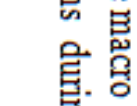 \\
\hline 象 & $\begin{array}{l}N \\
\stackrel{N}{0} \\
0\end{array}$ & $\stackrel{N}{\Xi}$ & $\begin{array}{l}\overrightarrow{8} \\
0 \\
0\end{array}$ & $\stackrel{\overrightarrow{0}}{\stackrel{\bullet}{0}}$ & $\begin{array}{l}\dot{\infty} \\
\stackrel{\infty}{0} \\
0\end{array}$ & $\begin{array}{l}\vec{\circ} \\
\stackrel{\circ}{\circ}\end{array}$ & పू & $\underset{⿱ 乛}{\vec{\Xi}}$ & 号 & \multirow{2}{*}{ 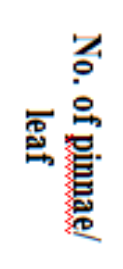 } & $\vec{v}$ \\
\hline : & $\stackrel{N}{N}$ & 莕 & 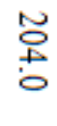 & 응 & - & $\stackrel{\overrightarrow{0}}{\bullet}$ & $\begin{array}{l}0 \\
\infty \\
0\end{array}$ & O & 客 & & 음 \\
\hline
\end{tabular}


spine/leaf during both seasons, respectively. These results were true during 2015 and 2016 seasons.

\section{1-7. Spine length:}

Data in Table (3) show that treating the palms three times with silicon as well as some macro and micronutrients singly or in combinations significantly was followed by stimulating the spine length compared to the control treatment. In the first season of study, using silicon or the mixture of micronutrients $(\mathrm{Zn}, \mathrm{Fe}, \mathrm{Mn}, \mathrm{Cu}$ and $\mathrm{B})$ had a slight promotion on the spine length relative to the control treatment. Using silicon with macro and/or micronutrients significantly superior than using each alone in enhancing such growth trait. The maximum values were recorded on the palms that treated three times with silicon and all nutrients. The lowest values were recorded on untreated palms. Similar trend was noticed during both seasons.

\section{2- Leaf mineral content:}

\section{2-1. Percentage of $N$ in the leaves:}

It is cleared from the obtained data in Table (4) that combined applications of silicon as well as macro and micronutrients was significantly very effective in improving the percentage of $\mathrm{N}$ in the leaves compared to the control treatment. Using silicon as well as some macro and micronutrients singly failed to show significant promotion on the percentage of $\mathrm{N}$ compared to the control treatment. Using silicon with all nutrients gave the maximum values of $\mathrm{N}(2.57 \& 2.44 \%)$ during both seasons, respectively. The lowest values were recorded on untreated palms. These results were true during both seasons.

\section{2-2. Percentage of $P$ in the leaves:}

Data in Table (4) that show the percentage of $\mathrm{P}$ in the leaves of Zaghloul date palms was significantly improved in response to single and combined applications of silicon and various nutrients over the control treatment. The promotion was associated with using silicon, micro and macronutrients, in ascending order. Using silicon besides macro and/or micro nutrients significantly surpassed the application of each group alone in enhancing the percentage of P. Percentage of P was maximized $(0.221 \& 0.241$ $\%)$ in the leaves from palms received silicon and all nutrients together during both seasons, respectively. Similar trend was noticed during both seasons. 


\begin{tabular}{|c|c|c|c|c|c|c|c|c|c|c|}
\hline \multirow{2}{*}{ 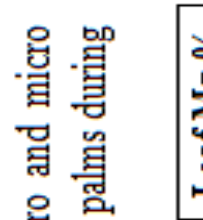 } & \multirow{2}{*}{ 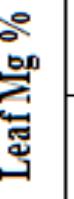 } & $\stackrel{\infty}{n}$ & 志 & 吉 & $\tilde{\sigma}$ & 'n & నุ & ร్ & হి & $\stackrel{2}{\circ}$ \\
\hline & & กั & 号 & 足 & 웅 & $\bar{E}$ & 志 & รุ & హ్ & 豙 \\
\hline 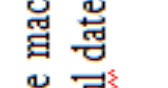 & \multirow{2}{*}{ 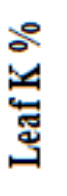 } & 壵 & 문 & 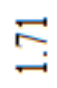 & $\stackrel{8}{-}$ & $\stackrel{\circ}{\circ}$ & $\stackrel{\text { gi }}{\text { in }}$ & $\stackrel{m}{2}$ & $\vec{r}$ & $\because$ \\
\hline 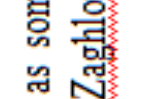 & & $\stackrel{\square}{\square}$ & 음 & $\stackrel{m}{\beth}$ & $\stackrel{8}{-}$ & 을 & $\underset{\sim}{\Xi}$ & $\underset{\sim}{\stackrel{a}{2}}$ & ป઼ & 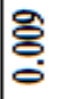 \\
\hline 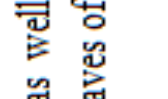 & \multirow{2}{*}{ 递 } & 응 & $\stackrel{m}{0}$ & $\stackrel{9}{m}$ & $\stackrel{2}{\circ}$ & $\underset{\Xi}{\Xi}$ & $\stackrel{ }{\frac{9}{0}}$ & $\stackrel{\infty}{\stackrel{\sim}{\Xi}}$ & 롱 & 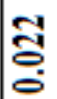 \\
\hline 总 & & $\stackrel{\Xi}{\Xi}$ & 응 & $\stackrel{9}{\Xi}$ & 웅 & 릉 & $\stackrel{\infty}{\stackrel{2}{0}}$ & $\stackrel{\Xi}{\Xi}$ & స઼ & 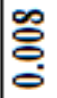 \\
\hline 古预 & \multirow{2}{*}{ 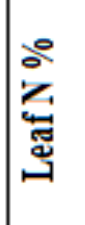 } & 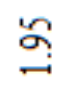 & 이 & 음 & $\underset{\sim}{\Xi}$ & ㄱ. & m্ & $m$ & $\underset{\sim}{+}$ & 옹 \\
\hline "مص, & & $\stackrel{\infty}{\infty}$ & $\stackrel{\varrho}{-}$ & 8 & 엄 & $\underset{\sim}{\infty}$ & 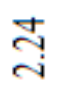 & $\stackrel{\infty}{\sim}$ & in & গి \\
\hline 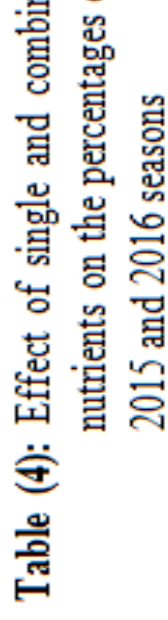 & 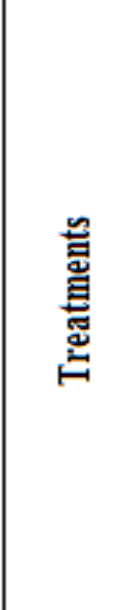 & 总 & 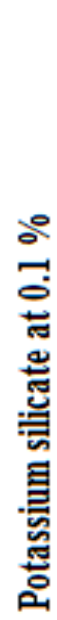 & 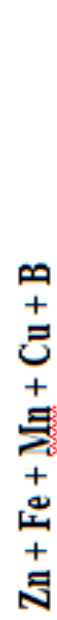 & $\begin{array}{l}\text { bo } \\
+ \\
+ \\
\text { v } \\
+ \\
0 \\
+ \\
z\end{array}$ & 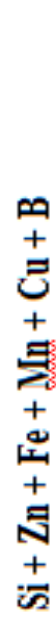 & $\begin{array}{l}\text { and } \\
+ \\
+ \\
+ \\
+ \\
0 \\
+ \\
4 \\
+ \\
+\end{array}$ & 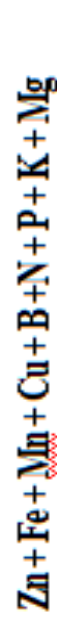 & 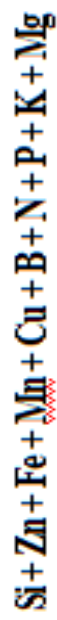 & 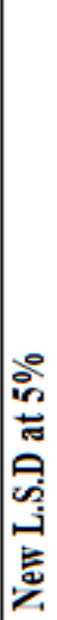 \\
\hline
\end{tabular}




\section{2-3. Percentage of $K$ in the leaves:}

It is worth to mention from the data obtained in Table (4) that single and combined applications of silicon and different nutrients significantly had promoted effects on the percentage of $\mathrm{K}$ in the leaves in the first season. However, in the second season using silicon alone caused a slight stimulation on the percentage of $\mathrm{K}$ in the leaves over the control treatment. Using macro and/or micronutrients besides silicon had significant promotion on the percentage of $\mathrm{K}$ compared with using nutrients without silicon. Using silicon with all nutrients gave the maximum values of $\mathrm{K} \%(2.31$ \& $2.27 \%)$ during both seasons, respectively. The lowest values were recorded on untreated palms.

\section{2-4. Percentage of $\mathrm{Mg}$ in the leaves:}

Data in Table (4) show that single and combined applications of silicon as well as macro and micronutrients were significantly very effective in enhancing $\mathrm{Mg}$ in the leaves compared to the control treatment. Using macro and/or micronutrients significantly enhanced $\mathrm{Mg} \%$ above the application of silicon alone. Supplying silicon to macro and/or micronutrients was significantly favourable than using macro or micronutrients alone in enhancing such nutrient in the leaves. Amending the palms with silicon and all nutrients (macro and micronutrients) gave the maximum values of $\mathrm{Mg}$ namely 0.94 and $0.99 \%$ during both seasons, respectively. These results were true during both seasons.

\section{DISCUSSION:}

The outstanding effect of silicon on growth, palm nutritional status, yield and fruit quality might be attributed to its positive action on enhancing the tolerance of plants to biotic and abiotic stresses (Ma, 2004), water retention; photosynthetic activity and water economy (Gang et al., 2003 and Hattori et al., 2005), water transport, root development (Lux et al., 2003 and Hattori et $a l ., 2003)$. The great strength on the plant tissues due to using silicon surely reflected on increasing the resistance to several disorders (Marschner, 1995). These results are in agreement with those obtained by Gad El-Kareem et al (2012) on Zaghloul date palms and Youssef (2017) on Sakkoti date palms.

According Marchner, (1995) the important regulatory effect of $\mathrm{N}$ on building of proteins, amino acids, enzymes, natural hormones, vitamins, antioxidants and plant pigments and encouraging photosynthesis and cell division, $\mathrm{P}$ in enhancing the biosynthesis of sugars, plant pigments, enzymes, natural hormones, cell division, vitamins, root development and 
photosynthesis, $\mathrm{K}$ in stimulating the biosynthesis and translocation of sugars, plant pigments, cell division, tolerance of fruit crops to biotic and abiotic stresses, water tolerance, root development, $\mathrm{Mg}$ in building chlorophylls and enhancing the biosynthesis of sugars, proteins and fats, sugars translocation and amino acid, Fe in building chlorophylls and plant pigments and regulating reduction and oxidants reactions, $\mathrm{Mn}$ in enhancing co-enzymes that are responsible for enhancing the activity of respiration and oxidation enzymes and the biosynthesis of organic acids, $\mathrm{N}$ metabolism, nitrate reduction and the biosynthesis of IAA, $\mathrm{Zn}$ in activating metabolism enzymes, biosynthesis of organic foods, IAA, cell division and enlargement, water absorption and nutrient transport and $\mathrm{B}$ in enhancing the biosynthesis of $\mathrm{N}$, proteins, IAA, carbohydrates, water uptake and pallor germination surely reflected on stimulating growth, palm nutritional status, yield and fruit quality of Zaghloul date palms.

These results are in agreement with those obtained by Desouky et al., (2007) on Barhee date palms; Shahin (2007) on Khalas date palms; Abdalla (2008) on Zaghloul date palms and Mohamed and Mohamed (2013) on Sakkoti date palms.

Conclusively, the best results with regard of Zaghloul date palms were obtained due to using a mixture of silicon and nutrients $(\mathrm{N}, \mathrm{P}, \mathrm{K}, \mathrm{Mg}, \mathrm{Zn}, \mathrm{Fe}$, $\mathrm{Mn}, \mathrm{Cu}$ and $\mathrm{B}$ ) three times.

\section{REFERENCES}

Abdalla, A.A. (2008): Behaviour of Zaghloul date pain to some pollen carriers and boron. M. Sc. Thesis Fac. of Agric. Minia Univ. Egypt.

Ahmed, F. F. and Morsy, M. H. (1999): A new method for measuring leaf area in different fruit species. Minia J. of Agric. Res. \& Develop., (19) 97-105.

Black, G. A.; Evans, D. D.; Ersminger, L. E.; White, J. L. and dark, F. E. (1965): Methods of Soil Analysis. Amer. Soc. Agron. Inc. Bull. Medison, Wisconsin, U.S.A. pp.891-1400.

Carter, M.R. (1993): Soil Sampling and Methods Analysis. Xandian Soc. Soil Sci. Lewis Publishers, London, Tokyo, ISBN-100873718615.

Chapman, H.D. and Pratt, P.E. (1965): Methods of Analysis for Soil, Plant and Water. Univ. of Calif. Divison of Agric. Sci., 172-173. 
Cottenie A; Verloo, M.; Velghe, M. and Camerlynck, R. (1982): Chemical Analysis of Plant and Soil. Ghent, Belgium, Laboratory of Analytical and Agro- chemistry. State Univ., pp. 200 - 210.

Desouky, L.M. ; El- Hamady, A.; Hassan, A. and Abdel- Hamid, A. (2007): Effect of spraying Barhee flower with potassium sulphate and boric acid on fruit set, productivity and date properties. $4^{\text {th }}$ Symp. On date Palm in Saudi Arabia (Challenges of Processing, Marketing and Pests Control). Date Palm Res. Center, King Faisal Univ., Al Hassa 5-8 May, Abstracts Book pp. 76.

Evenhuis, B. and Deword, P.W. (1980): Principles And Practices In Palm Analysis. F.A.O. Soil and Bull 38; 163- 172.

Gad El- Kareem, M.R.; Abdelaal, A.M.K. and Mohamed A.Y. (2014): the synergistic effect of using silicon and selenium on fruiting of Zaghloul date palm (Phoenic dectylifera L.) World Academy of ci. Engineering and Technology, Inter. J. of Agric. Biosystems Sci. and Engineering, 8 (3):959-964.

Gang, H.J.K.; Chen, K.M.; Chen, G.C.; Wan, S.M. and Zhang, C.L. (2003): Effect of silicon on growth of wheat under drought. H. Plant. Nutr., 26(5):1055-1063.

Gomez, K. A. and Gomez, A. A. (1984): Statistical Procedures for Agriculture Research. John Wiley and Sons, New York, pp. 130.

Hattori, T; Inanaga, S.; araki, H.; An, P.; Martia, S.; Luxova, M. and Lux, A. (2005): Application of silicon enhanced drought tolerance in Sorgham bicolor. Physiologia Plantarum, 123:459-466.

Hussein, M.A.; Mahmoud, H.M. and Ahmed- Amin- Kamelia, l. (1987): Effect of certain pollen storage treatments of bunch weight and fruit quality of Zaghloul dates. Assiut. J. of Agric. Sc. , 18(2): 275283.

Jones, J. R. B.; Wolf, B. and Mills, H. A. (1991): Plant Analysis Handbook, Micro- Macro publishing Inc., Georgia U.S.A. Chapter 7 pp. 45 - 88.

Lux, A.; Luxova, M.; Abe, J.; Tanmoto, E. and Inanaga, S. (2003): The dynamic of silicon deposition in the sorghum root endodermis. New Physiol., 158:437-441.

Ma, J.F. (2004): Role of silicon in enhancing the resistance of plants of biotic and abiotic stresses. Soil Scr. Plant Nutr., 50:11-18.

Marschner, P. (1995): Mineral Nutrition of Higher Plants. Marschner (Ed.) Academic press. Third edition. Mineral Nutrition. Yield and Source-Sink Relationships. pp.115-116. Elsevier. 
Mead, R., Curnow, R. N. and Harted, A. M. (1993). Statistical Methods in Agricultural and Experimental Biology. $2^{\text {nd }}$ Ed. Chapman \& Hall, London pp. 10-44.

Mohamed, Y.A. and Mohamed, H.H. (2013): The synergistic effects of using turmeric with various nutrients on fruiting of Sewy date palms. Hort. Science Journal of Suez Canal Univ., 1 : 287-291.

Musa, I.A. (1981): Evaluation studies of some seedling date palms grown at Ismailia province M. Sc. Thesis Fac. of Agric. Zagazig Univ. Egypt.

Omar, A.I.A. (2015): Effect of spraying seaweed extract and potassium silicate on growth and fruiting of Al- Saidey date palms. M. Sc. Thesis Fac. of Agric. Minia Univ. Egypt.

Page, A.L., Miller, R.H. and Keeney, D.R. (1982): Methods of Soil Analysis. Part 2 Amer. Soc. of Agron, Madison, U.S.A., pp. 10- 17.

Peach, K. and Tracey, I.M.V. (1968): Modern Methods of Plant Analysis, 11 pp. 3 6- 38.

Piper, C.S. (1950): Soil and Plant Analysis, Inter Science New York pp 48110.

Pregel, F. (1945): Quantitive Organic Micro Analysis. 4Ed. J. th A. Churchill Ltd., London, pp:53.

Shahin, M., (2007): Effect of Potassium fertilization on growth, leaves nutrient content, and yield of "Khalas" date palm in Al-Hassa Oasis (K.S.A). The Fourth Symposium on Date Palm in Saudi Arabia (Challenges of Processing, Marketing, and Pests Control), Date Palm Research Center, King Faisal University, AI-Hassa. 5-8 May, 2007. Abstracts Book, pp: 77.

Summer, M.E. (1985): Diagnosis and Recommendation. Integrated system (DRIS) as a guide to orchard fertilization. Hort. Abst., 55(8): 7502.

Yousef, M.S.M. (2017): Effect of spraying silicon on fruiting of Sakkoti date palms. M.Sc. Thesis Fac. of Agric. Minia Univ. Egypt. 
تأثير رش السيليكون وبعض العناصر الغذائية علي النمو والحالة الغذائية

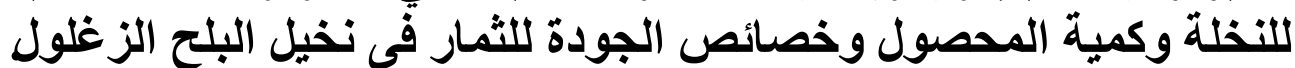

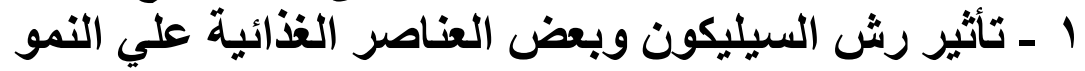

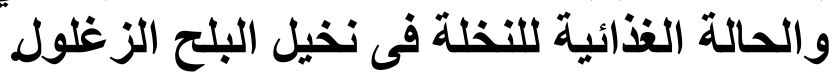

أحمد محمد محمد أبو زيد عقل* ، فيصل فاضل أحمد حسن*، حمدى إبراهيم محمود

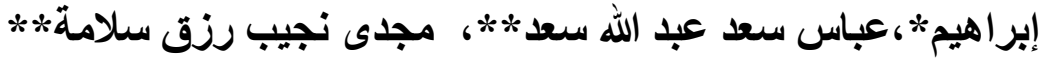

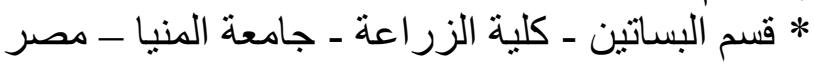

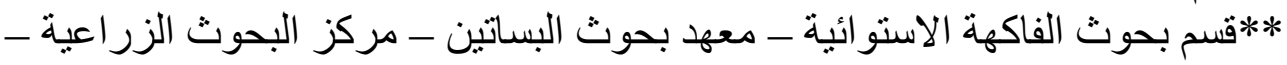

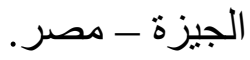

خلال موسمى 2015، 2016 نم رش نخيل البلح الزغلول في منطقة مغاغة المغية

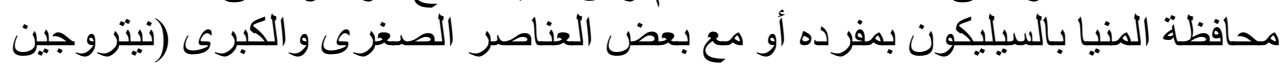

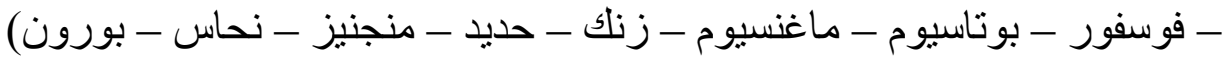
وكان الهدف هو اختيار تأثير هذه العناصر الغذائية علي النمو والحالة الغذائية الغئية للنخلة.

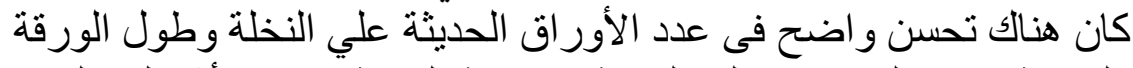

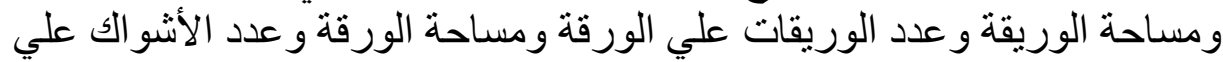

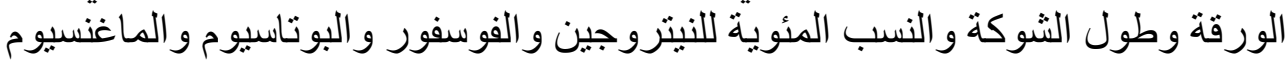

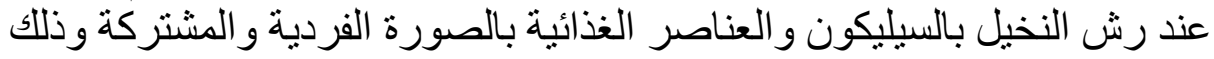

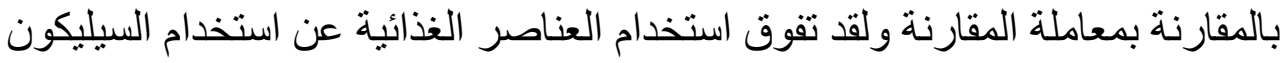

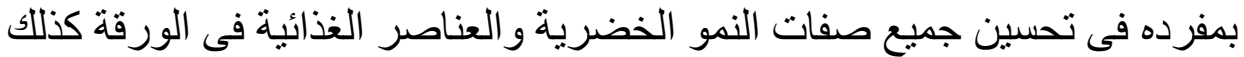

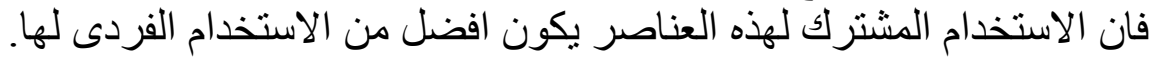

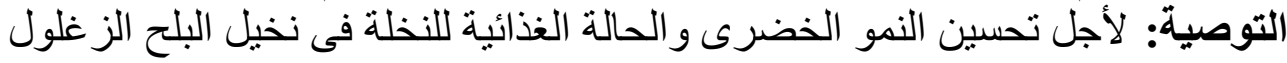

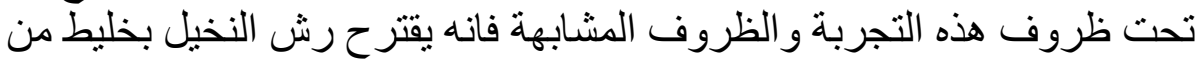

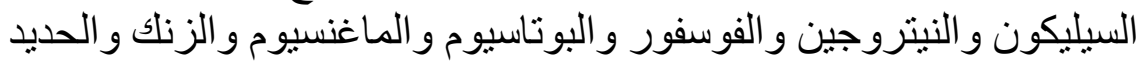
و المنجنيز و النحاس و البورون ثلاث مر اتل 
